\title{
Pengendalian Pemanfaatan Ruang Kawasan Terdampak Banjir Di Perkotaan Sinjai
}

\author{
Space Utilization Control Flood-Affected Areas in Sinjai Urban \\ Muhammad Afandi Naser', Murshal Manaf ${ }^{1,2,3}$, Tri Budiharto ${ }^{1}$
}

\begin{abstract}
${ }^{1}$ Program Studi Perencanaan Wilayah \& Kota, Fakultas Teknik,Universitas Bosowa Makassar
${ }^{2}$ Program Studi Pascasarjana Perencanaan Wilayah dan Kota, Fakultas Teknik, Universitas Bosowa Makassar

${ }^{3}$ Program Studi Doktoral Perencanaan Wilayah dan Kota, Fakultas Teknik, Universitas Bosowa Makassar

Email : afandymuhammad07@gmail.com
\end{abstract}

\section{Artikel info}

\section{Artikel history:}

Diterima; 09-03-2021

Direvisi: 25-03-2021

Disetujui;30-03-2021

\begin{abstract}
This study aims to explain the characteristics of flood-affected areas, in order to analyze land suitability and spatial use in flood-affected areas and to formulate the concept of controlling the spatial use of floodaffected areas. This research is qualitative-quantitative with the analysis techniques used are scoring analysis, superimpose analysis, qualitative descriptive analysis and space envelope analysis. The results show that there are three classifications of flood hazard, namely low, medium and high, where in the high flood-prone areas in Sinjai city there are five villages, namely Balangnipa Village, Biringere Village, Bongki Village, Lappa Village and Samataring Village. The results of the second research objective were obtained from the overlay prone to flooding and the spatial pattern of the Sinjai urban RDTR, where the dominant spatial pattern of high flood prone areas is in the housing zone which covers an area of 564,185 hectares. The direction of the strategic concept based on three classifications offlood hazard in Sinjai urban areas is proposed in the form of disaster mitigation in the form of recommendations for flood control in accordance with the characteristics of flood-prone areas, and in controlling spatial use in the form of zoning regulations and permit proposals at the research location granting land use permits for each area prone to high, medium and low flood disasters.
\end{abstract}

Abstrak. Penelitian ini bertujuan untuk menerangkan karakteristik kawasan terdampak banjir, guna menganalisis kesesuaian lahan dan pemanfaatan ruang pada kawasan terdampak banjir dan merumuskan konsep pengendalian pemanfaatan ruang kawasan terdampak banjir. Penelitian ini bersifat kualitatif-kuantitatif dengan teknik analisis yang digunakan adalah analisis skoring, analisis superimpose, analisis deskriptif kualitatif dan analisis amplop ruang. Hasil penelitian diketahui bahwa terdapat tiga klasifikasi kerawanan banjir yaitu rendah, sedang dan tinggi yang dimana pada kawasan rawan banjir tinggi di perkotaan Sinjai terdapat di lima kelurahan yaitu Kelurahan Balangnipa, Kelurahan Biringere, Kelurahan Bongki, Kelurahan Lappa dan Kelurahan Samataring. Adapun hasil tujuan penelitian kedua yang didapat dari overlaynya rawan banjir dan pola ruang RDTR perkotaan Sinjai, dimana yang berdominan pada pola ruang kawasan rawan banjir tinggi terdapat di zona perumahan yang luasnya sebesar 564.185 Ha. Arahan konsep strategi berasarkan tiga klasifikasi kerawanan banjir di kawasan perkotaan Sinjai diusulkan dalam bentuk mitigasi bencana berupa rekomendasi pengendalian banjir yang sesuai dengan karakteristik pada kawasan rawan banjir, dan pada pengendalian pemafaatan ruang berupa peraturan zonasi dan usulan perizinan di lokasi penelitian dapat disimpulkan bahwa terdapat perbedaan perilaku pemberian perizinan penggunaan lahan pada setiap kawasan rawan bencana banjir tinggi, sedang maupun rendah. 


\section{Keywords:}

Control of Spatial Use;

Floods; Mitigation;

Disaster; Sinjai City.
Coresponden author:

Email: afandymuhammad07@gmail.com

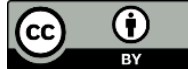

artikel dengan akses terbuka dibawah lisensi CC BY -4.0

\section{PENDAHULUAN}

Banjir adalah suatu kondisi dimana tidak tertampungnya air dalam saluran pembuang (palung sungai) atau terhambatnya aliran air didalam saluran pembuang, sehingga meluap mengenai daerah (dataran banjir) sekitarnya .Pada kawasan perkotaan, banjir pada umumnya disebabkan oleh beberapa hal diantaranya: curah hujan tinggi, pengaruh fisografi, erosi dan sedimentasi pada saluran, pendangkalan sungai, kapasitas drainase yang kurang memadai, kawasan kumuh, sampah, alih fungsi lahan, dan perencanaan penanggulangan banjir yang tidak tepat (Cahyadi et al., 2012). Pada wilayah-wilayah tertentu, banjir merupakan ancaman bencana musiman dan hal ini dialami pula oleh Kabupaten Sinjai dimana setiap tahunnya kawasan perkotaan Sinjai selalu dilanda oleh bencana banjir dengan cakupan wilayah yang cukup luas dan kerap kali memberi kerugian yang besar terhadap masyarakat dan pemerintah. Bencana banjir yang selama ini kerap melanda kawasan perkotaan Sinjai, yang memiliki ketinggian genangan antara 30-70 cm dengan lama waktu tergenang mencapai 3-9 jam atau lebih tergantung dengan lama turun hujan yang terjadi di kawasan perkotaan Sinjai. Secara spesifik lama waktu banjir kawasan perkotaan Sinjai di pengaruhi oleh beberapa aspek antara lain drainase yang tersumbat, lama hujan di kawasan perkotaan Sinjai, luapan air dari sungai yang ada di sekitaran kawasan perkotaan, minimnya daerah resapan yang ada di wilayah permukiman serta kondisi topografi yang rendah di kawasan perkotaan Sinjai. Aspekaspek tersebut menjadi dasar dalam menentukan lama waktu banjir yang terjadi. Pada dasarnya bencana banjir yang kerap melanda kawasan perkotaan Sinjai tersebut memiliki karakteristik yang berbeda-beda, dan hal ini sangat dipengaruhi oleh ketinggian lahan, bentuk permukaan lahan, intensitas curah hujan dan jenis tanah yang dimiliki oleh masing-masing kawasan terdampak banjir di kawasan perkotaan Sinjai.

Dari keseluruhan kawasan perkotaan Sinjai yang saat ini merupakan pusat konsentrasi penduduk dan kegiatan sosial ekonomi serta pemerintahan, terdapat empat kelurahan yang setiap tahunnya selalu dilanda bencana banjir, yaitu Kelurahan Lappa, Kelurahan Balangnipa, Kelurahan Biringere dan Kelurahan Samataring. Empat wilayah kelurahan ini merupakan daerah yang selalu berlanggganan banjir setiap tahunnya dan mendapatkan dampak yang cukup besar berupa kerusakan sarana dan prasarana umum, kerusakan bangunan tempat tinggal/rumah dan juga perabotan rumah. Terkait dengan empat lokasi tersebut, juga dijelaskan dalam dokumen RDTR dan PZ kawasan perkotaan Sinjai Tahun 2018-2038, bahwa ke empat kelurahan tersebut merupakan daerah rawan tergenang banjir di perkotaan Sinjai. Banjir yang terjadi di kawasan perkotaan sangat berpengaruh terhadap kondisi sosial dan ekonomi masyarakat setempat, dengan adanya banjir kegiatan atau aktifitas masyarakat menjadi terganggu apalagi dengan kondisi kawasan perkotaan Sinjai yang merupakan pusat segala pelayanan dalam lingkup Kabupaten Sinjai maka untuk itu diperlukanya suatu konsep penanganan banjir, agar kawasan perkotaan yang terdampak banjir secara perlahan bisa dikendalikan atau dikurangi dampak dari datangnya bencana banjir di kemudian hari, terlebih lagi dengan kondisi kawasan perkotaan Sinjai yang dilintasi oleh dua sungai besar di Kabupaten Sinjai yaitu Sungai Tangka dan Sungai Mangottong.

Pengendalian pemanfaatan ruang merupakan salah satu bentuk dari upaya penataan ruang yang diselenggarakan untuk mewujudkan tertib tata ruang melalui upaya pembuatan zonasi, penyelenggaraan perizinan, pemberian insentif dan disinsentif serta pengenaan sanksi sehingga pemanfaatan ruang dapat berjalan sesuai dengan rencana tata ruang yang telah ditetapkan. Tujuan dari pengendalian pemanfaatan ruang adalah untuk tercapainya konsistensi pemanfaatan ruang dengan rencana tata ruang yang telah ditetapkan. Oleh karena itu, dengan melihat betapa pentingnya upaya pengendalian pemanfaatan ruang dalam kegiatan penataan ruang di kawasan perkotaan Sinjai dan juga kondisinya yang rentan terhadap banjir serta wilayahnya yang dilintasi oleh dua sungai besar, maka sudah seharusnya diperlukan sebuah konsep upaya pengendalian pemanfaatan ruang yang dapat menjadi alat pengendali terhadap pemanfaatan ruang di dalam kawasan perkotaan Sinjai, khususnya pada kawasan yang terdampak banjir. Berangkat dari keseluruhan pembahasan latar berlakang di atas, maka peneliti tertarik untuk mengangkat judul penelitian terkait dengan judul Pengendalian Pemanfaatan Ruang Kawasan Terdampak Banjir Di Perkotaan Sinjai. 


\section{METODE}

\subsection{Jenis Penelitian}

Penelitian ini bertujuan untuk mengetahui karaktersitik kawasan terdampak banjir sekaligus merumuskan konsep pengendalian pemanfaatan ruang kawasan terdampak banjir yang terdapat di kawasan perkotaan Sinjai, dengan menggunakan pendekatan penelitian kuantitatif dan kualitatif. yang dimana penelitian kuantitatif menurut Sugiyono (2014) dalam jurnal (Mahendra, n.d.) adalah data yang bisa diselidiki secara langsung dan bisa dihitung dengan menggunakan cara yang mudah, serta penelitian kualitatif adalah data yang berbentuk bukan angka atau menjelaskan secara deskripsi tentang kondisi lokasi penelitian secara umum.

\subsection{Lokasi dan Waktu Penelitian}

Penelitian ini dilaksanakan di ibu kota Kabupaten Sinjai yaitu kawasan perkotaan Sinjai, yang dimana secera keseluruhan kawasan perkotaan Sinjai memiliki luas wilayah $\pm 40.31 \mathrm{Km}^{2}$ yang terdistribusi pada 8 wilayah Kelurahan. Dimana kawasan perkotaan Sinjai merupakan salah satu kawasan perkotaan yang selalu dilanda bencana banjir setiap tahunya.Waktu penelitian berlangsung dari bulan Agustus. Dengan beberapa tahapan diantaranya observasi lapangan, wawancara mastarakat, kemudian pengambilan data di instansi, serta penyusunan laporan.

\subsection{Kerangka Pikir}

Menurut Uma Sekaran dalam jurnal (Hikmah, 2019) mengemukakan bahwa kerangka berpikir merupakan model konseptual tentang bagaimana teori berhubungan dengan berbagai faktor yang telah diidentifikasi sebagai hal yang penting, jadi dengan demikian maka kerangka berpikir adalah sebuah pemahaman yang melandasi pemahaman-pemahaman yang lainnya, sebuah pemahaman yang paling mendasar dan menjadi pondasi bagi setiap pemikiran atau suatu bentuk proses dari keseluruhan dari penelitian yang akan dilakukan. Adapun kerangka pikir dalam penelitian ini dapat dilihat pada gambar berikut ini ;

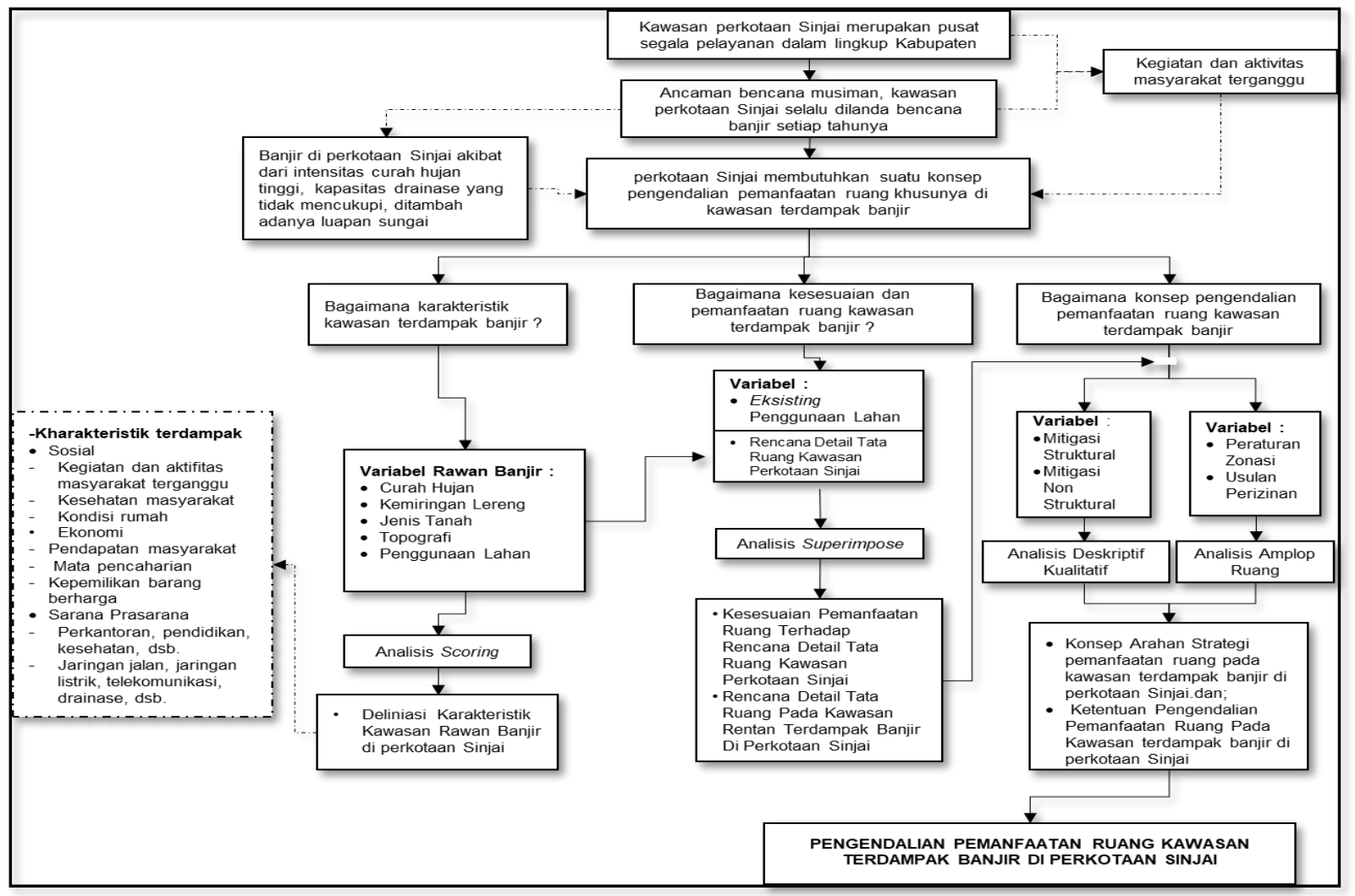

Gambar 1. Bagan Kerangka Pikir

\subsection{Jenis dan Sumber Data}

\subsubsection{Jenis Data}

Dalam penelitian ini, data yang digunakan yaitu data kuantitatif dan kualitatif menurut Sugiyono (2014). Data kuantitatif adalah data yang bisa diselidiki secara langsung dan bisa dihitung dengan menggunakan cara yang 
mudah sedangkan data kualitatif adalah data yang berbentuk bukan angka atau menjelaskan secara deskripsi tentang kondisi lokasi penelitian secara umum. (Mahendra, n.d.)

\subsubsection{Sumber Data}

Kemudian untuk sumber data peneliti menggunakan sumber data primer dan data sekunder :

a) Data primer yaitu data yang diperoleh secara langsung melalui pengamatan langsung ke lapangan atau lokasi penelitian, data primer yang dibutuhkan antara lain data penggunaan lahan/eksisting, data kawasan rawan banjir di perkotaan Sinjai dan lain sebagainya.

b) Data sekunder yaitu data yang diperoleh melalui dokumen-dokumen resmi menyangkut penelitian ini yang didapatkan dari berbagai instansi terkait seperti data jumlah penduduk, data aspek fisik dasar yang di dapatkan dari Badan Pusat Statistik (BPS) Kabupaten Sinjai.

Tabel 1. Sumber Data Penelitian

\begin{tabular}{|c|c|c|c|c|}
\hline No & Jenis Data & Sumber Data & $\begin{array}{l}\text { Teknik Pengumpulan } \\
\text { Data }\end{array}$ & Tempat Perolehan Data \\
\hline 1 & $\begin{array}{l}\text { Data distribusi dan luas } \\
\text { wilayah Kabupaten Sinjai dan } \\
\text { kawasan kerkotaan Sinjai }\end{array}$ & Data Primer & $\begin{array}{c}\text { Survey Wawancara dan } \\
\text { Obsevasi Lapangan }\end{array}$ & $\begin{array}{c}\text { Badan Pusat Statistik } \\
\text { Kabupaten Sinjai }\end{array}$ \\
\hline 2 & $\begin{array}{l}\text { Data kependudukan } \\
\text { Kabupaten Sinjai dan } \\
\text { kawasan perkotaan Sinjai }\end{array}$ & $\begin{array}{c}\text { Data } \\
\text { Sekunder }\end{array}$ & Survey Data Sekunder & $\begin{array}{l}\text { Badan Pusat Statistik } \\
\text { Kabupaten Sinjai }\end{array}$ \\
\hline 3 & $\begin{array}{l}\text { Data jenis dan luas } \\
\text { penggunaan lahan kawasan } \\
\text { perkotaan Sinjai }\end{array}$ & $\begin{array}{c}\text { Data Primer } \\
\text { dan Sekunder }\end{array}$ & $\begin{array}{l}\text { Observasi Lapangan dan } \\
\text { Interprestasi Peta Citra } \\
\text { Satelit }\end{array}$ & $\begin{array}{c}\text { Data Lapangan, Citra Satelit } \\
\text { SASPlanet, dan Citra Satelit Google } \\
\text { Earth Tahun } 2019\end{array}$ \\
\hline 4 & $\begin{array}{l}\text { Data bencana banjir kawasan } \\
\text { perkotaan Sinjai }\end{array}$ & $\begin{array}{c}\text { Data Primer } \\
\text { dan Sekunder }\end{array}$ & $\begin{array}{l}\text { Observasi Lapangan dan } \\
\text { Interprestasi Peta Citra } \\
\text { Satelit }\end{array}$ & $\begin{array}{c}\text { Badan Penanggulangan } \\
\text { Bencana Alam }\end{array}$ \\
\hline 5 & $\begin{array}{l}\text { Dokumen RTRW Kabupaten } \\
\text { Sinjai beserta database } \\
\text { shepfile }\end{array}$ & $\begin{array}{c}\text { Data } \\
\text { Sekunder }\end{array}$ & Survey Data Sekunder & BAPEDA Kabupaten Sinjai \\
\hline 6 & $\begin{array}{l}\text { Dokumen RDTR kawasan } \\
\text { perkotaan Sinjai }\end{array}$ & $\begin{array}{c}\text { Data } \\
\text { Sekunder }\end{array}$ & Survey Data Sekunder & BAPEDA Kabupaten Sinjai \\
\hline 7 & $\begin{array}{l}\text { Peta-peta yang mendukung } \\
\text { penelitian ini }\end{array}$ & $\begin{array}{c}\text { Data } \\
\text { Sekunder }\end{array}$ & Survey Data Sekunder & $\begin{array}{c}\text { BAPEDA Kabupaten Sinjai, Citra } \\
\text { Satelit SASPlanet, dan Citra Satelit } \\
\text { Google Earth Tahun } 2019\end{array}$ \\
\hline 8 & $\begin{array}{l}\text { Data Kondisi Fisik Lahan } \\
\text { kawasan perkotaan Sinjai }\end{array}$ & $\begin{array}{c}\text { Data } \\
\text { Sekunder }\end{array}$ & Survey Data Sekunder & $\begin{array}{c}\text { BAPEDA/PU } \\
\text { Kabupaten Sinjai }\end{array}$ \\
\hline
\end{tabular}

\subsection{Populasi dan Sampel}

\subsubsection{Popilasi}

Populasi adalah jumlah keseluruhan dari satuan-satuan atau individu-individu yang karakteristiknya hendak diteliti. Satuan-satuan tersebut dinamakan unit analisis, dan dapat berupa orangorang, institusi-institusi, bendabenda dan lain sebagainya (Diawranto,1994:420) dalam jurnal (JOURNAL OF BUSINESS STUDIES, 2016).

Dalam penelitian ini, populasi yang menjadi fokus penelitian adalah penduduk yang bermukim di kawasan perkotaan Sinjai sebesar 54.181 jiwa, yang mengalami dampak dari bencana banjir.

\subsubsection{Sampel}

Sampel adalah bagian dari jumlah karakterristik yang dimiliki oleh populasi yang diteliti.Sampel yang baik adalah sampel yang bersifat representatif atau yang dapat menggambarkan karakteristik populasi secara menyeluruh terkait dengan judul penelitian dalam penyusunan tugas akhir ini, teknik sampling yang digunakan yaitu nonprobability dengan teknik purposive sampling,

Teknik purposive sampling adalah teknik untuk menentukan sampel penelitian dengan beberapa pertimbangan tertentu yang bertujuan agar data yang diperoleh nantinya bisa lebih representatif (Mukhsin et al., n.d.). Alasan menggunakan teknik purposive sampling adalah karena tidak semua sampel memiliki kriteria yang sesuai dengan fenomena yang diteliti. Oleh karena itu, penulis memilih teknik purposive sampling yang menetapkan pertimbangan-pertimbangan atau kriteria-kriteria tertentu yang harus dipenuhi oleh sampel-sampel yang digunakan dalam penelitian ini. Adapun banyaknya jumlah sampel dalam penelitian ini akan ditentukan 
dengan menggunakan rumus slovin.

Teknik slovin menurut Sugiyono dalam (Pradana \& Reventiary, 2016) menetapkan rumus slovin dalam menentukan Sampel adalah sebagai berikut:

$$
n=\frac{N}{1+N e^{2}}
$$

Dimana :
$n$ : jumlah sampel
$\mathrm{N}$ : jumlah populasi
e: batas toleransi kesalahan (error tolerance) $1 \%, 10 \%$ dan $15 \%$

Dalam penelitian ini untuk tingkat kesalahan dalam penarikan sampel akan digunakan persentase sebesar $10 \%$, dan untuk lebih jelasnya mengenai jumlah sampel dalam penelitian ini adalah sebagai berikut:

$$
\begin{aligned}
& \mathrm{n}=\mathrm{N} /\left(1+\left(\mathrm{N} . \mathrm{e}^{2}\right)\right) \\
& \mathrm{n}=54.181 /\left(1+\left(54.181 \times 0,1^{2}\right)\right) \\
& \mathrm{n}=54.181 / 542,81 \\
& \mathrm{n}=99,8(\text { dibulatkan menjadi } 100 \text { sampel) }
\end{aligned}
$$

Dari hasil perhitungan diatas dapat disimpulkan bahwa jumlah sampel yang akan digunakan dalam penelitian ini sebagai perwakilan dari keseluruhan populasi adalah sebanyak 100 jiwa penduduk. 100 jiwa penduduk inilah yang kelak akan dijadikan sebagai responden pada saat penelitian dilakukan.

\subsection{Metode Analisis}

Metode analisis yang digunakan untuk menjawab tiga tujuan penelitian dalam penelitian ini, terdapat empat analisis yaitu analisis skoring, analisis superimpose, analisis deskriptif kualitatif dan analisis amplop ruang. yang dimana pengertian dari ke empat analisis sebagai berikut :

a) Analisis Skoring adalah teknik analisis data kuantitatif yang digunakan untuk memberikan nilai pada masingmasing karakteristik parameter dari sub-sub variabel agar dapat dihitung nilainya serta dapat ditentukan peringkatnya. (Gunawan et al., 2014)

b) Analisis Superimpose/Overlay adalah analisis spasial esensial yang menjadi masukanya. Secara umum teknis mengenai analisis ini terbagi ke dalam format data raster dan vektor. (Emelyana et al., 2017)

c) Winaeta 2006 menjelaskan bahwa analisis deskriptif kualitatif merupakan analisis yang digunakan untuk menganalisa, menggambarkan dan meringkas berbagai kondisi situasi dari berbagai data yang dikumpulkan dari hasil wawancara atau pengamatan mengenai masalah yang di teliti pada lokasi penelitian. (Muuzi et al., n.d.)

\begin{tabular}{|c|c|c|c|c|}
\hline No & Tujuan Penelitian & Analisis & Variabel & Keluaran \\
\hline 1 & $\begin{array}{l}\text { Menerangkan Karakteristik } \\
\text { kawasan terdampak banjir }\end{array}$ & Analisis Skoring & $\begin{array}{l}\text { - Curah Hujan } \\
\text { - Kemiringan Lereng } \\
\text { - Jenis Tanah } \\
\text { - Topografi } \\
\text { - Penggunaan Lahan }\end{array}$ & $\begin{array}{l}\text { - Deleniasi Karakteristik } \\
\text { Kawasan Terdampak Banjir } \\
\text { Di Perkotaan Sinjai }\end{array}$ \\
\hline 2 & $\begin{array}{l}\text { Guna menganalisis } \\
\text { kesesuaian lahan dan } \\
\text { pemanfaatan ruang pada } \\
\text { kawasan terdampak banjir }\end{array}$ & Analisis Superimpose & $\begin{array}{l}\text { - Eksisting Penggunaan Lahan } \\
\text { - RDTR Kawasan Perkotaan } \\
\text { Sinjai }\end{array}$ & $\begin{array}{l}\text { - Peta Kesesuaian } \\
\text { Pemanfaatan Ruang } \\
\text { Terhadap Rencana Detail } \\
\text { Tata Ruang Kawasan } \\
\text { Perkotaan Sinjai } \\
\text { - Peta RDTR Kawasan } \\
\text { terdampak Banjir di } \\
\text { Perkotaan Sinjai }\end{array}$ \\
\hline \multirow[t]{2}{*}{3} & $\begin{array}{l}\text { Merumuskan konsep } \\
\text { pengendalian pemanfaatan } \\
\text { ruang kawasan terdampak } \\
\text { banjir }\end{array}$ & $\begin{array}{l}\text { Analisis Deskriptif } \\
\text { Kualitatif }\end{array}$ & $\begin{array}{l}\text { - Mitigasi Struktural } \\
\text { - Mitigasi Non-Struktural }\end{array}$ & $\begin{array}{l}\text { Konsep Arahan Strategi } \\
\text { pemanfaatan ruang pada } \\
\text { kawasan terdampak banjir di } \\
\text { perkotaan sinjai }\end{array}$ \\
\hline & & Analisis Amplop Ruang & $\begin{array}{l}\text { - Peraturan Zonasi } \\
\text { - Usulan Perizinan }\end{array}$ & $\begin{array}{l}\text { Ketentuan Pengendalian } \\
\text { Pemanfaatan Ruang pada } \\
\text { kawasan terdampak banjir di } \\
\text { perkotaan Sinjai }\end{array}$ \\
\hline
\end{tabular}

d) Prinsip analisis amplop ruang iyalah terciptanya ruang yang akomodatif terhadap berbagai jenis kegiatan yang direncanakan, dalam mewujudkan keserasian dan keasrian lingkungan, dengan menetapkan intensitas pemanfaatan lahan didalam kawasan.(Priyono, n.d.)

Tabel 2. Metode Penelitian 


\subsubsection{Analisis Skoring}

Analisis Scoring ini digunakan untuk menentukan daerah rawan banjir dengan menggunakan metode overlay dengan scoring antara parameter-parameter yang ada, yaitu kemiringan lereng, curah hujan, topografi, jenis tanah dan penggunaan lahan. Dari semua parameter ini nantinya akan di scoring dengan pemberian bobot dan nilai sesuai dengan pengklasifikasiannya masing-masing yang kemudian dilakukan overlay menggunakan software ArcGIS 10.3 , adapun prosedur pemberian harkat dan bobot mengacu pada penelitian-penelitian sebelumnya serta pedoman Kementrian PU. Pemberian bobot masing-masing parameter atau variabel berbeda-beda, yaitu dengan memperhatikan seberapa besar pengaruh parameter tersebut terhadap terjadinya banjir maka nilai bobotnya besar, sebaliknya jika pengaruhnya kecil maka nilai bobotnya juga kecil. Untuk lebih jelasnya dapat dilihat pada tabel berikut ini :

Tabel 3. Klasifikasi Kemiringan Lereng,Jenis Tanah,Curah Hujan, Penggunaan Lahan dan Topografi

\begin{tabular}{|c|c|c|c|c|}
\hline Variabel & Indikator & Skor & Bobot & Total Skor \\
\hline \multirow{4}{*}{$\begin{array}{l}\text { Curah } \\
\text { Hujan }\end{array}$} & $4000-4500 \mathrm{~mm}$ & 4 & & 80 \\
\hline & $3500-4000 \mathrm{~mm}$ & 3 & & 60 \\
\hline & $2500-3000 \mathrm{~mm}$ & 2 & 20 & 40 \\
\hline & $2000-2500 \mathrm{~mm}$ & 1 & & 20 \\
\hline \multirow[t]{4}{*}{ Kemiringan Lereng } & $0-2 \%$ & 4 & & 40 \\
\hline & $2-5 \%$ & 3 & & 30 \\
\hline & $5-15 \%$ & 2 & 10 & 20 \\
\hline & $>15 \%$ & 1 & & 10 \\
\hline \multirow{4}{*}{$\begin{array}{l}\text { Jenis } \\
\text { Tanah }\end{array}$} & Aluvial & 4 & & 40 \\
\hline & Glesol & 3 & & 30 \\
\hline & Kambisol & 2 & 10 & 20 \\
\hline & Podzolik, Mediteran & 1 & & 10 \\
\hline \multirow[t]{4}{*}{ Penggunaan Lahan } & Permukiman dan tempat kegiatan & 4 & & 80 \\
\hline & Sawah,tambak & 3 & & 60 \\
\hline & Mangrove & 2 & 20 & 40 \\
\hline & Semak Belukar & 1 & & 20 \\
\hline \multirow[t]{4}{*}{ Topografi } & 0-1 Mdpl & 4 & & 40 \\
\hline & 1-3 Mdpl & 3 & & 30 \\
\hline & 3-8 Mdpl & 2 & 10 & 20 \\
\hline & $>8 \mathrm{Mdpl}$ & 1 & & 10 \\
\hline
\end{tabular}

Penentuan kelas dalam Penelitian ini tergantung dari hasil perolehan skor bobot total. Jumlah variabel yang digunakan dalam penelitian ini adalah 5. Penentuan interval kelas lahan kawasan rawan banjir dapat diperoleh dari "total skor tertinggi dikurangi dengan total skor terendah, kemudian dibagi dengan jumlah kelas lahan". Berdasarkan formulasi tersebut, maka penentuan interval kelas kawasan rawan berpotensi banjir di perkotaan Sinjai adalah sebagai berikut: 
Muhammad Afandi Naser, Murshal Manaf, Tri Budiharto/ Journal of Urban and Regional Spatial. Vol 01 No 02. Hal $147-164$

$\begin{array}{ll}\text { Interval Kelas Lahan } & =\frac{280-70}{3} \\ & =\frac{210}{3} \\ & =70\end{array}$

Dari hasil perhitungan interval di atas dengan menggunakan 3 pembagian kelas lahan, maka dapat diketahui bahwa jenjang nilai interval untuk masing-masing kelas lahan adalah sebesar 70. Dan dari nilai interval 70 tersebut, maka didapati bahwa kesesuaian lahan untuk penentuan kawasan rawan berpotensi banjir di perkotaan Sinjai adalah sebagaimana di uraikan pada berikut:

Tabel 4. Klasifikasi Kelas Lahan Kawasan Rawan Banjir

\begin{tabular}{clc}
\hline No & \multicolumn{1}{c}{ Kelas Lahan } & Total Skor \\
\hline 1 & Kawasan Rawan Banjir Rendah & $70-140$ \\
2 & Kawasan Rawan Banjir Sedang & $141-210$ \\
3 & Kawasan Rawan Banjir Tinggi & $211-280$ \\
\hline
\end{tabular}

\subsubsection{Analisis Superimpose}

Untuk menjawab rumusan masalah ke 2 menggunakan analisis superimpose/overlay, yang dimana keluaran Analisis superimpose ini menghasilkan 2 peta yaitu peta kesesuaian pemanfaatan ruang terhadap RDTR kawasan perkotaan Sinjai dan peta rencana detail tata ruang kawasan rawan banjir. Analisis overlay adalah prosedur penting dalam analisis SIG (sistem informasi geografis). Overlay yaitu kemampuan untuk menempatkan grafis satu peta diatas grafis peta yang lain dan menampilkan hasilnya di layar komputer atau pada plot. Secara singkatnya, overlay menampalkan suatu peta digital pada peta digital yang lain beserta atribut-atributnya dan menghasilkan peta gabungan keduanya yang memiliki informasi atribut dari kedua peta tersebut (Emelyana et al., 2017). Teknik yang digunaan untuk overlay peta dalam SIG ada 2 yakni union dan intersect. Jika dianalogikan dengan bahasa Matematika, maka union adalah gabungan, intersect adalah irisan.

\subsubsection{Analisis Kesesuaian Pemanfaatan Ruang Terhadap RDTR Kawasan Perkotaan Sinjai}

Analisis ini dilakukan dengan cara mengoverlay peta Eksisting penggunaan lahan kawasan perkotaan Sinjai dan peta RDTR kawasan perkotaan Sinjai yang dimana hasil dari proses overlay tersebut menghasilkan peta baru yaitu peta kesesuaian pemanfaatan ruang terhadap RDTR kawasan perkotaan Sinjai, langkah selanjutnya yaitu membandingkan kondisi penggunaan lahan eksisting terhadap RDTR, sehingga diperoleh data informasi kesesuaian lahan dengan 2 (dua) kriteria kesesuaian yaitu sesuai dan tidak sesuai.

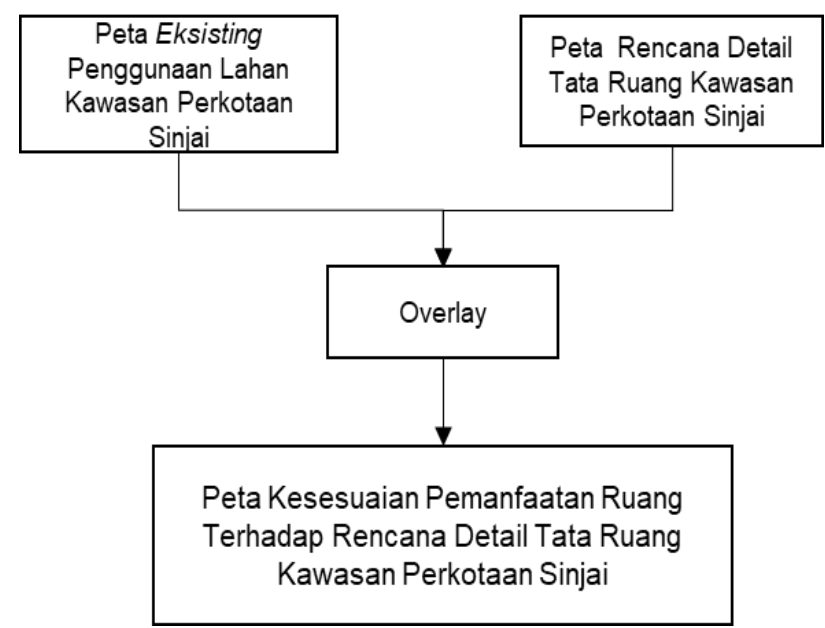

Gambar 2. Proses Overlay Peta eksisting Penggunaan Lahan dan Peta RDTR Kawasan Perkotaan Sinjai

\subsubsection{Analisis Pemanfaatan Ruang Kawasan Rawan Banjir Pada RDTR Kawasan Perkotaan Sinjai}

Analisis ini dilakukan dengan cara menoverlay peta RDTR kawasan perkotaan Sinjai dengan peta kerawanan banjir di kawasan perkotaan Sinjai. hasil keluaran dari overlay ini pun iyalah peta rencana detail tata ruang kawasan rawan banjir, yang nantinya di bagi menjadi tiga peta sesuai dengan klasifikasi dari peta kerawanan 
banjir kawasan perkotaan Sinjai.

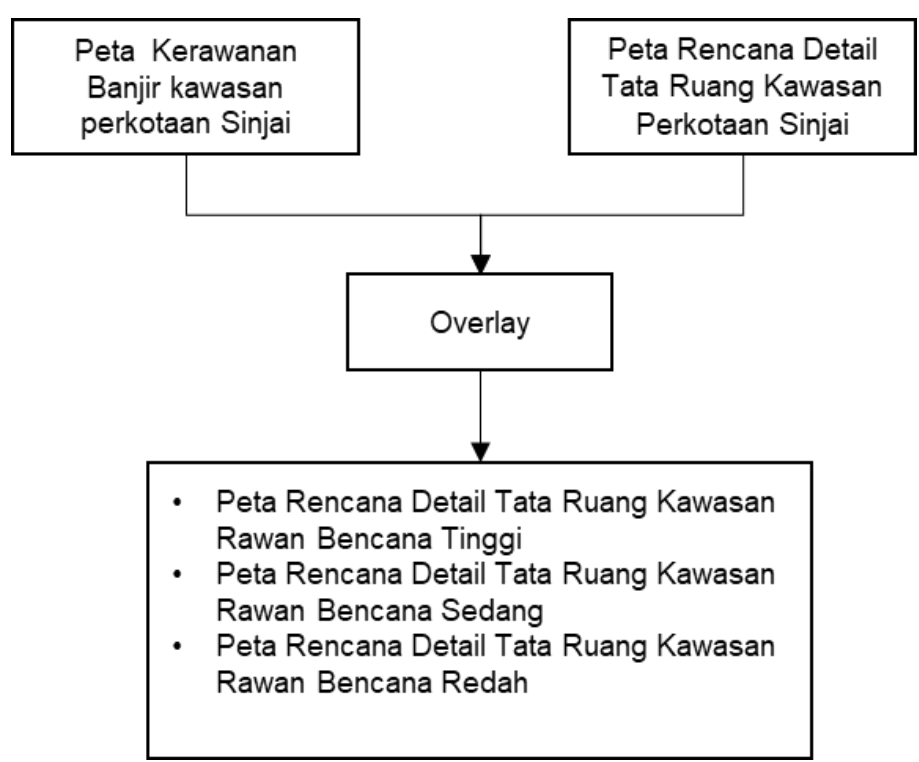

Gambar 3. Proses Overlay Peta Kerawanan Banjir dan Peta RDTR Kawasan Perkotaan Sinjai

\subsubsection{Analisis Deskriptif Kualitatif}

Untuk menjawab rumusan masalah ke tiga penulis menggunakan metode analisis deskriptif kualitatif. Analisis deskriptif kualitatif digunakan untuk bagaimana menganalisa arahan pemanfaatan ruang kawasan terdampak banjir yang dilihat berdasarkan aspek potensi terjadinya gejala banjir pada kawasan perkotaan tersebut. Adapun isi analisis deskriptif yang digunakan yaitu metode struktural dan metode non-struktural, metode ini di uraikan seperti berikut :

\subsubsection{Metode Struktural}

Metode struktural merupakan upaya yang dilakukan demi meminimalisir bencana seperti dengan melakukan pembangunan danal khusus untuk mencegah banjir dan dengan membuat rekayasa teknis bangunan tahan bencana, serta infrastrukur bangunan tanah air. Dimana infrastruktur bangunan yang tahan air nantinya diharapkan agar tidak memberikan dampak yang begitu parah apabila bencana tersebut terjadi.

\subsubsection{Metode Non-Struktural}

Mitigasi non-struktural adalah upaya yang dilakukan selain mitigasi struktural seperti dengan perencanaan wilayah dan asuransi. Dalam mitigasi non-struktural ini sangat mengharapkan dari perkembaangan teknologi yang semakin maju. harapanya adalah teknologi yang dapat mempredikisi, mengantisipasi dan mengurangi resiko terjadinya suatu bencana.(Gina, n.d.)

\subsubsection{Analisis Amplop Ruang}

Prinsip analisis amplop ruang iyalah terciptanya ruang yang akomodatif terhadap berbagai jenis kegiatan yang direncanakan, dalam mewujudkan keserasian dan keasrian lingkungan, dengan menetapkan intensitas pemanfaatan lahan didalam kawasan. Dalam analisis amplop ruang terdapat empat aspek upaya penataan ruang yang diselenggarakan untuk mewujudkan tertib tata ruang melalui upaya pembuatan zonasi, penyelenggaraan perizinan,pemberian insentif dan disinsentif serta pengenaan sanksi namun dalam penelitian ini hanya meliputi upaya perumusan peraturan zonasi dan perizinan,yang dimana akan di uraikan sebagai berikut:

\subsubsection{Peraturan Zonasi}

Peraturan zonasi pada dasarnya adalah suatu alat untuk pengendalian yang mengatur tentang persyaratan pemanfaatan ruang dan ketentuan pengendalianya yang disusun untuk setiap blok/zona peruntukan (UU No. 26 Tahun 2007 tentang Penataan Ruang),dimana blok/zona peruntukan yang menjadi acuan ditetapkan melalui rencana rinci tata ruang. Peraturan zonasi ini lebih dikenal dengan istilah populer zoning regulation, dimana kata zoning yang dimaksud merujuk pada pembagian lingkungan kota ke dalam zona-zona pemanfaatan ruang dimana didalam tiap zona tersebut ditetapkan pengendalian pemanfaatan ruang atau diberlakukan ketentuan hukum yang berbeda-beda. Adapun peraturan 
zonasi atau zoning regulation ini di beberapa negara lain diberlakukan dengan istilah yang berbeda-beda,antara lain zoning code,land development code, zoning ordinance, zoning resolution, zoning bby law, dan sebagainya. (Kautsary, 2018)

\subsubsection{Usulan Perizinan}

Perizinan merupakan upaya untuk memperbolehkan atau tidak memperbolehkan suatu kegiatan berlangsung pada suatu wilayah sesuai dengan tata ruang, dengan mengeluarkan penerbitan surat izin. Adapun dalam penelitian kali ini mencoba membuat/memberi arahan usulan perizinan pada kawasan rentan banjir sesuai dengan tiga klasifikasi kerentanan yaitu tinggi, sedang maupun rendah yang dimana dalam pemberian arahan perizinan, peneliti mencoba untuk membuat usulan perizinan pada pola ruang yang terdampak bencana banjir yang terdapat di kawasan rentan banjir tinggi, sedang maupun rendah pada kawasan perkotaan Sinjai. Dalam pelaksanaan perizinan hal-hal yang perlu dilakukan adalah menyusun mekanisme perizinan dan kelembagaan yang terkait dalam perizinan.

\section{a. Arahan Perizinan}

Arahan perizinan pemanfaatan ruang merupakan acuan bagi penertiban pemanfaatan ruang pada tingkat operasional, yaitu yang diberikan pada pemanfaatan ruang di tingkat kabupaten/kota dan kecamatan, seperti izin prinsip, Izin Memberkan Bangunan (IMB), Izin gangguan (HO), dan izin tepat usaha. Semua jenis perizinan pemanfaatan ruang pada prinsipnya harus diintegrasikan dan sesuai dengan tujuan penataan ruang provinsi yang dijabarkan secara rinci ke dalam RTRW Kabupaten/kota dan rencana yang lebih rinci lainya. Secara umum perizinan pemanfaatan ruang dapat diberikan dengan ketentuan sebagai berikut :

- Perizinan diberikan terhadap kegiatan-kegiatan yang sesuai dengan rencana pola ruang dan merujuk pada arahan indikasi peraturan zonasi.

- Poses perizinan untuk setiap kegiatan merujuk pada peraturan dan peraturan perundang-undangan yang berlaku pada masing-masing sektor.

- Pemberi izin pemanfaatan ruang diberikan oleh instansi pemerintah yang berwenang sesuai dengan kewenanganya sebagaimana diatur dalam PP No. 38 tahun 2007 dan peraturan perundangan lain yang berlaku.

b. Mekanisme Perizinan

Mekanisme perizinan merupakan prosedur penting dalam upaya penyelarasan pemanfaatan ruang dengan ketentuan indikasi arahan peraturan zonasi yang tertuang dalam penataan ruang wilayah. Prosedur proses yang perlu dilakukan dalam perizinan pemanfaatan ruang Pendaftaran

Dilakukan untuk lokasi ruang yang akan diminta izin pemanfaatan ruang. Data yang disampaikan meliputi status kepimilikan tanah, rencana penggunaan yang diertai denah lokasi, rencana bangunan yang disertai peta rencana, persetujuan dari dinas terkait dan warga sekitar lokasi yang akan digunakan. Data tersebut diserahkan kepada pihak atau lembaga yang berwenang mengurus dan/atau memberi izin pemanfaatan ruang.

- Advis Planning

Setelah proses pendaftaran selesai, selanjutnya dilakukan konfirmasi atas izin yang diajukan terhadap rencana pola ruang dan indikasi arahan peraturan zonasi yang diberlakukan oleh tim advis planning yang berwenang. Selain itu tim advis planning juga melakukan cek lapangan atas lokasi yang dimintakan izin pemanfaatan ruang dan proses perizinan akan dilanjutkan apabila permintaan izin memenuhi ketentuan pola ruang dan indikasi arahan peraturan zonasi.

- Penetapan Perizinan

Hasil dari tim advis planning diberikan kepada lembaga yang berwenang memberikan izin pemanfaatan ruang sesuai dengan kewenangannya. Dalam hal ini tentunya disertai dengan persyaratan yang harus dipenuhi oleh pemohon sesuai ketentuan yang diberlakukan pada kawasan/lokasi yang bersangkutan. (Kautsary, 2018)

\section{HASIL DAN PEMBAHASAN}

\subsection{Hasil}

\subsubsection{Gambaran Umum Lokasi Penelitian}

Kawasan perkotaan Sinjai terletak di dua Kecamatan di Kabupaten Sinjai yaitu Kecamatan Sinjai Utara dan Kecamatan Sinjai Timur, Kecamatan Sinjai Utara merupakan wilayah pusat kota terdiri dari 6 Kelurahan 
diantaranyaKelurahan Alewanue,KelurahanBiringere,KelurahanLamatti Rilau,Kelurahan Bongki,Kelurahan Balangnipa dan Kelurahan Lappa. Sedangkan Kecamatan Sinjai Timur yang masuk dalam deleniasi kawasan perkotaan terdapat 2 kelurahan/desa yaitu Kelurahan Samataring dan Desa Saukang. Secara keseluruhan kawasan perkotaan Sinjai memiliki luas wilayah $\pm 40.31 \mathrm{Km}^{2}$ yang terdistribusi pada 8 wilayah Kelurahan.

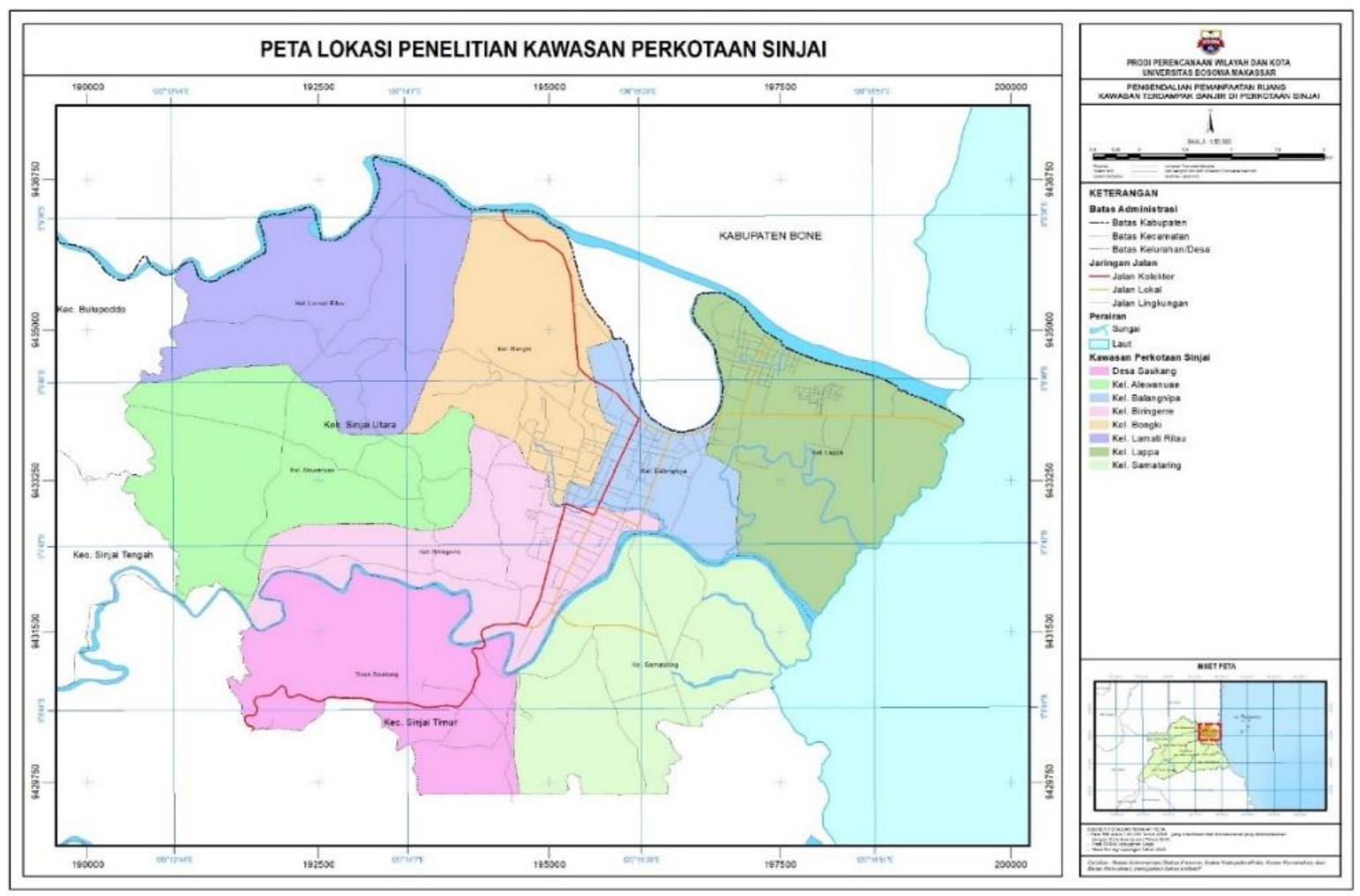

\subsubsection{Historikal Bencana Banjir Perkotaan Sinjai}

Gambar 4. Peta Administrasi Kawasan Perkotaan Sinjai

Kabupaten Sinjai merupakan wilayah yang sering terjadi bencana banjir setiap tahunya, dan terdapat dua wilayah rawan banjir di Kabupaten Sinjai yang dimana wilayah tersebut masuk pada kawasan perkotaan Sinjai yaitu Kecamatan Sinjai utara dan Kecamatan Sinjai Timur. Adapun data yang peneliti dapatkan dari hasil observasi Badan Penanggulangan Bencana Daerah (BPBD) dalam kurun 5 tahun terakhir menyebutkan bahwa ada beberapa kelurahan yang sering terkena bencana banjir hampir setiap tahunya di kawasan perkotaan Sinjai yaitu Kelurahan Biringere, Kelurahan Balangnipa dan Kelurahan Lappa, pada tahun 2019, lebih jelasnya dapat dilihat pada tabel berikut:

Tabel 5. Data Bencana Banjir Dalam Kurun Waktu 5 Tahun Terakhir

\begin{tabular}{cclcccccc}
\hline No & Kecamatan & Kelurahan & \multicolumn{3}{c}{ Data Bencana Banjir Dalam Kurun Waktu 5 Tahun Terakhir } \\
\hline \multirow{3}{*}{1} & \multirow{2}{*}{ Sinjai Utara } & & 2014 & 2015 & 2016 & 2017 & 2018 & 2019 \\
\cline { 3 - 8 } & & Kel. Alewanuae & - & - & - & - & - & - \\
& & Kel. Biringere & 1 & - & - & 1 & 1 & 5 \\
& & Kel. Lamatti Rillau & - & - & - & - & - & - \\
& & Kel. Bongki & - & - & - & 1 & - & - \\
& & Kel. Balangnipa & 1 & - & - & 1 & 1 & 3 \\
2 & \multirow{2}{*}{ Sinjai Timury } & Kel. Lappa & 1 & - & - & 1 & 1 & 1 \\
& & Desa Saukang & - & - & - & - & - & - \\
& & Kel. Samataring & - & - & - & 1 & - & - \\
\hline
\end{tabular}

\subsection{Pembahasan}

\subsubsection{Analisis Kawasan Rawan Bencana Banjir Pada Kawasan Perkotaan Sinjai}

Berdasarkan hasil analisis dengan menggunakan Arcgis 10.3 Wilayah banjir tingkat kawasan rawan banjir rendah (tidak rawan atau tidak berpotensi banjir) mempunyai luasan 1077.254 Ha atau 27\% dari luas kawasan perkotaan Sinjai. Luasan banjir dengan kondisi tingkat kawasan rawan banjir sedang (rawan) mencapai 1713.259 Ha atau $42 \%$ dri luas kawasan perkotaan Sinjai. Sedangkan tingkat kawasan rawan banjir tinggi (sangat rawan 
terkena banjir) mempunyai luasan $1240.943 \mathrm{Ha}$ atau $31 \%$ dari luas kawasan perkotaan Sinjai. Untuk lebih jelasnya dapat dilihat pada tabel :

Tabel 6. Luas Kawasan Rawan Banjir Masing-Masing Kelurahan Di Perkotaan Sinjai

\begin{tabular}{|c|c|c|c|c|c|}
\hline \multirow[t]{2}{*}{ No } & \multirow[t]{2}{*}{ Kecamatan } & \multirow[t]{2}{*}{ Kelurahan } & \multicolumn{3}{|c|}{ Luas Kawasan Rawan Banjir (Ha) } \\
\hline & & & Rendah & Sedang & Tinggi \\
\hline \multirow[t]{6}{*}{1.} & \multirow[t]{6}{*}{ Sinjai Utara } & Kel. Alewanuae & 96.648 & 263.864 & - \\
\hline & & Kel. Biringere & 161.240 & 158.390 & 127.705 \\
\hline & & Kel. Lamatti Rillau & 243.464 & 354.909 & - \\
\hline & & Kel. Bongki & 46.115 & 381.680 & 12.433 \\
\hline & & Kel. Balangnipa & - & 38.158 & 186.934 \\
\hline & & Kel. Lappa & - & 11.766 & 545.648 \\
\hline \multirow[t]{3}{*}{2} & \multirow[t]{2}{*}{ Sinjai Timur } & Desa Saukang & 174.893 & 340.073 & - \\
\hline & & Kel. Samataring & 96.648 & 166.027 & 366.643 \\
\hline & Total & & 1077.254 & 1713.259 & 1240.943 \\
\hline
\end{tabular}

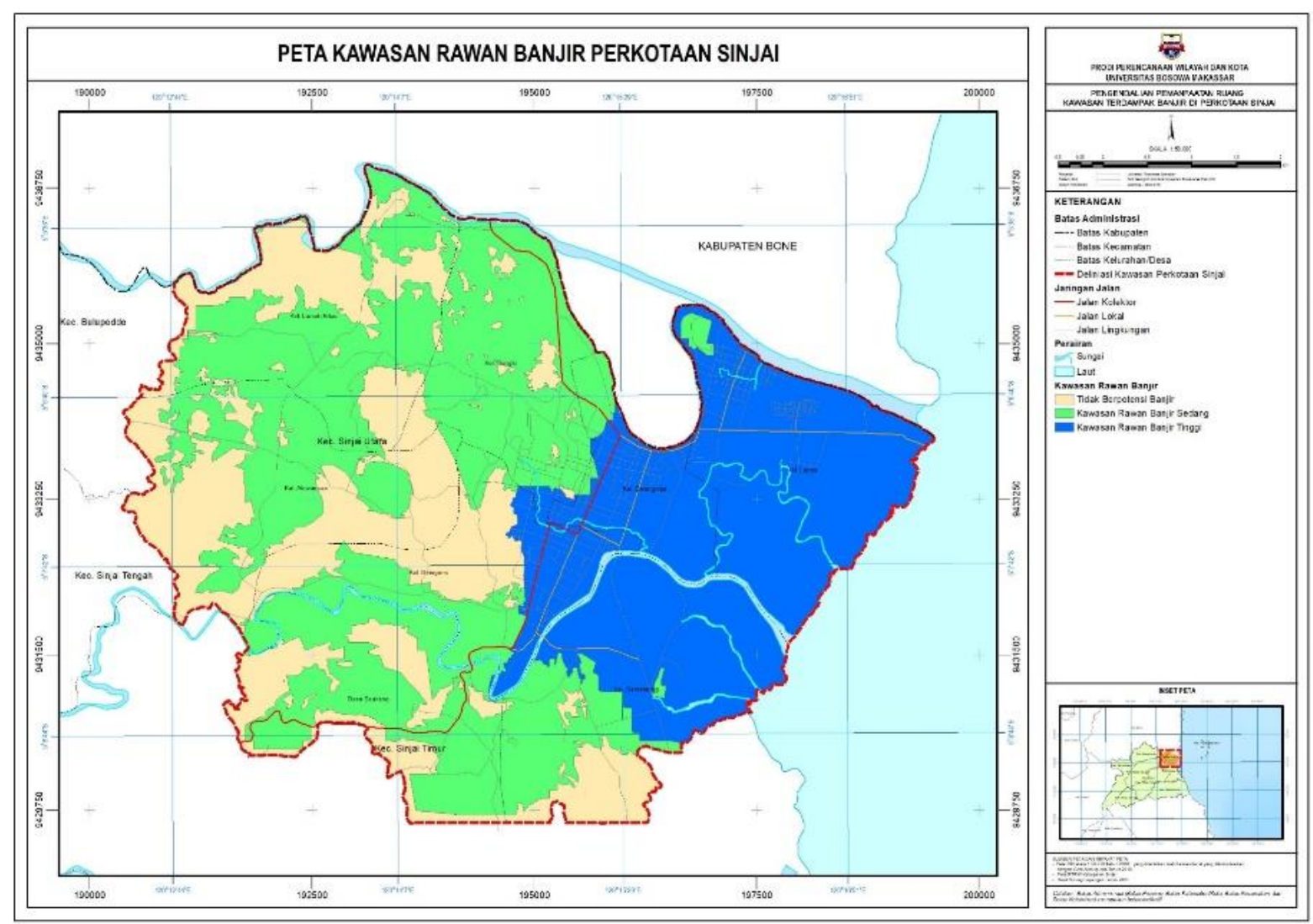

Gambar 5. Peta Kawasan Rawan Banjir Di Perkotaan Sinjai

\subsubsection{Analisis Kesesuaian Pemanfaatan Ruang Terhadap RDTR Kawasan Perkotaan Sinjai}

Berdasarkan hasil analisis yang telah dilakukan diketahui bahwa keseuaian pemanfaatan ruang terhadap Rencana Detail Tata Ruang kawasan perotaan Sinjai, yang diklasifikasikan dengan dua kriteria kesesuaian lahan didapatkan bahwa yang mendominasi pada kriteria Sesuai yaitu penggunaan lahan Zona Peruntukan Lainya yang memiliki luas sebesar 1.240,084 Ha, dan penggunaan lahan yang mendominasi pada kriteria Tidak Sesuai yaitu penggunaan lahan Zona Perumahan yang memiliki luas sebesar 791.425 Ha. Adapun pada keseluruhan luas kesesuaian penggunaan lahan terhadap Rencana Detail Tata Ruang kawasan perkotaan Sinjai,terdapat kesesuaian pemanfaatan ruang (Sesuai) lebih mendominasi yang memiliki luas sebesar 1.783.081 Ha. Namun terdapat penyimpangan pemanfaatan ruang di kawasan perkotaan Sinjai yang pembangunannya tidak sesuai dengan rencana pemanfaatan ruang yang sudah di tetapkan, pada penggunaan lahan yang tidak sesuai dengan rencana pemanfaatan ruang memiliki luas sebesar $193.302 \mathrm{Ha}$.

\subsubsection{Analisis Pemanfaatan Ruang Kawasan Terhadap RDTR Kawasan Perkotaan Sinjai}

Analisis pemanfaatan ruang kawasan rawan banjir di perkotaan Sinjai. Analisis pemanfaatan ruang ini digunakan untuk mengeluarkan rumusan maslah ke 2. Analisis ini dilakukan dengan cara meoverlay peta kerawanan 
banjir di perkotaan Sinjai yang sudah di buat sebelumnya dengan peta RDTR kawasan perkotaan Sinjai yang di mana output dari hasil overlay tersebut adalah peta rencana detail tata ruang kawasan rawan banjir, dan di bagi dalam 3 kawasan rawan banjir dengan klasifikasi kerawanan banjir yaitu sangat rawan banjir (Tinggi), rawan banjir (Sedang), dan kurang rawan banjir (Rendah), berikut merupakan rencana detail tata ruang kawasan rawan banjir pada perkotaan Sinjai :

\subsubsection{Analisis Pemanfaatan Ruang Kawasan Rawan Banjir Tinggi Pada RDTR Perkotaan Sinjai}

Berdasarkan hasil analisis di dapatkan bahwa wilayah kawasan perkotaan Sinjai yang memiliki tingkat kerawanan tinggi terdapat di 5 kelurahan di kawasan perkotaan Sinjai yaitu Kelurahan Biringere, Kelurahan Balangnipa, Kelurahan Lappa, Kelurahan Bongki dan Kelurahan Samataring yang dimana kawasan rawan banjir tinggi atau sangat rawan di dominsi oleh Zona Perumahan yang luasnya sebesr 564.185 Ha.

\subsubsection{Analisis Pemanfaatan Ruang Kawasan Rawan Banjir Sedang Pada RDTR Perkotaan Sinjai}

Berdasarkan hasil analisis dari di overlaynya peta kerawanan dan peta RDTR didapatkan bahwa kawasan rawan banjir sedang terdapat dan tersebar di 7 kelurahan di kawasan perkotaan Sinjai yang dimana 7 kelurahan tersebut adalah Kelurahan Lappa, Kelurahan Biringere, Kelurahan Balangnipa, Kelurahan Samataring, Kelurahan Bongki, Kelurahan Lamatti Rilau dan Desa Saukang, yang dimana kawasan rawan banjir sedang di dominasi oleh Perumahan dengan luasanya sebesar $689.837 \mathrm{Ha}$.

\subsubsection{Analisis Pemanfaatan Ruang Kawasan Rawan Banjir Rendah Pada RDTR Perkotaan Sinjai}

Berdasarkan hasil analisis di dapatkan bahwa kawasan rawan banjir rendah atau dalam klasifikasi kerawanan banjir di artikan sebagai kawasan yang jarang terkena bencana banjir yang memiiki kerawananya rendah, Adapun pola ruang yang memiliki kerawananya rendah terdapat di 5 Kelurahan/Desa yaitu Desa Saukan, Kelurahan Alewanuae, Kelurahan Lamatti Rilau, Kelurahan Bongki dan sebagian Kelurahan Biringere, yang dimana pola ruang yang berdominasi adalah Resapa Air dan Pertanian yang masing-masing memiliki luas sebesar 783.648 Ha dan 639.861 Ha yang tersebar di seluruh kelurahan yang terdapat di kawasan rawan banjir rendah.

\subsubsection{Analisis Konsep Strategi Pengendalian Pemanfaatan Ruang Kawasan Terdampak Banjir Di Perkotaan Sinjai}

\subsubsection{Arahan Konsep Strategi Penanganan Kawasan Rawan Terdampak Banjir Di Perkotaan Sinjai}

Penanganan kawasan rawan banjir dapat dilakukan dengan beberapa hal. Berdasarkan hasil analisis tingkat kerawanan banjir di kawasan perkotaan Sinjai diketahui pembagian zona daerah rawan banjir berdasarkan tingkat keawanannya yang di bagi atas tiga zona yaitu Zona A dengan kategori daerah yang sangat rawan terhadap banjir (kerawanan tinggi), Zona B daerah yang rawan (kerawanan sedang) terhadap banjir, dan Zona C daerah yang agak rawan atau tingkat kerawanan yang rendah terhadap banjir. Arahan pemanfaatan ruang wilayah dilakukan berdasarkan tingkat kerawanan wilayah terhadap banjir. Adapun Rekayasa Struktural Mitigasi Bencana dan Rekaya Non-Struktural Mitigasi Bencana pada kawasan terdampak banjir di perkotaan Sinjai dapat dilihat pada tabel sebagai berikut:

Tabel 7. Arahan Strategi Penanganan Kawasan Rawan Terdampak Banjir Di Perkotaan Sinjai

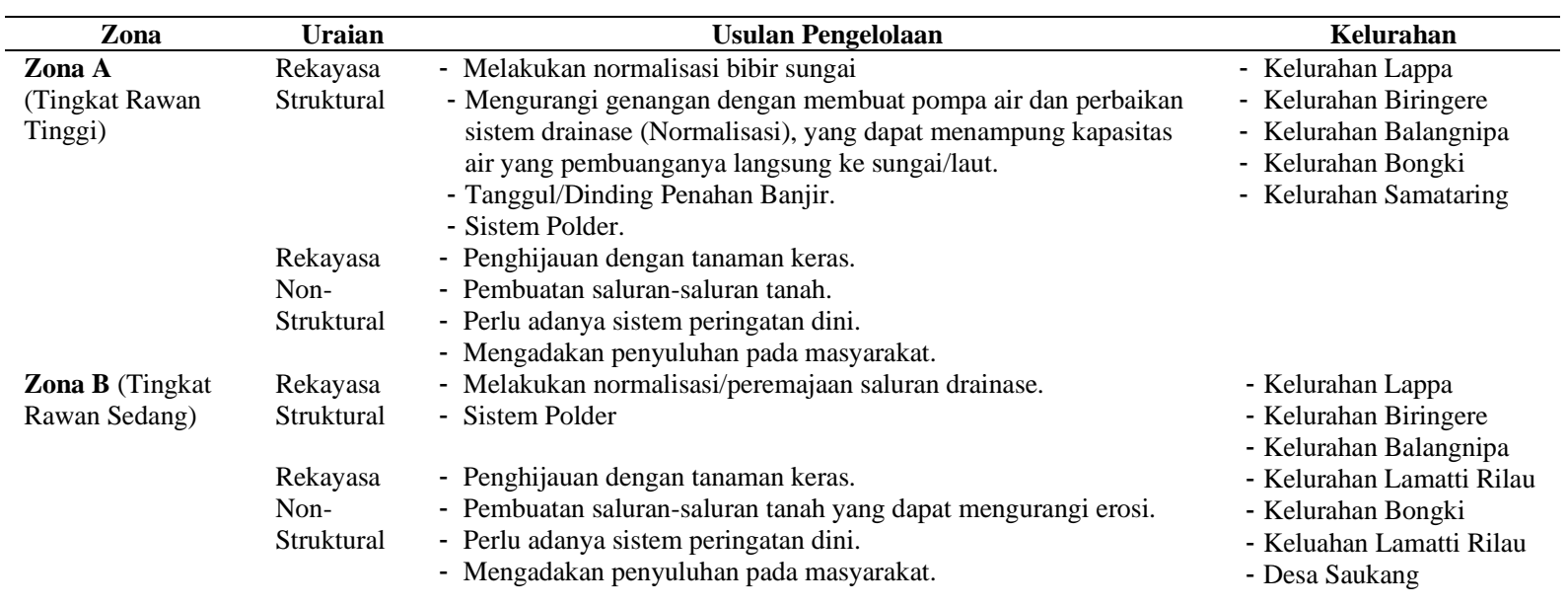


Muhammad Afandi Naser, Murshal Manaf, Tri Budiharto/ Journal of Urban and Regional Spatial. Vol 01 No 02. Hal $147-164$

\begin{tabular}{llll}
\hline \multicolumn{1}{c}{ Zona } & Uraian & Usulan Pengelolaan & Kelurahan \\
\hline Zona C (Tingkat & Rekayasa & - Pengelolaan DAS & - Kelurahan Alewanuae \\
Rawam Rendah) & Non- & - Pengaturan Tata Guna Lahan & - Kelurahan Lamatti Rilau \\
& Struktural & & - Kelurahan Bongki \\
& & & - Kelurahan Biringere \\
& & & - Desa Saukang \\
\hline
\end{tabular}

\subsubsection{Analisis Amplop Ruang}

Dalam penelitian kali ini peneliti memilih analisis amplop ruang untuk menciptakan pengendalian pemanfaatan ruang kawasan yang terdampak banjir di perkotaan Sinjai, yang dimana pengendalian pemanfaatan ruang merupakan salah satu bentuk dari upaya penataan ruang yang diselenggarakan untuk mewujudkan tertib tata ruang melalui upaya peraturan zonasi dan usulan perizinan (Putri, n.d.). Peraturan zonasi berisi ketentuan yang harus, boleh dan tidak boleh dilaksanakan pada zona pemanfaatan ruang yang dapat terdiri dari atas ketentuan tentang koefisien dasar ruang hijau, koefisien dasar bangunan, koefisien lantai bangunan serta ketentuan lainya yang dibutuhkan untuk mewujudkan ruang yang aman, nyaman, produktif dan berkelanjutan pada kawasan terdampak banjir di perkotaan Sinjai. Adapun analisis amplop ruang dalam penelitian ini merupakan wujud dari pengendalian pemanfaatan ruang yang mengatur tentang peraturan zonasi dan usulan perizinan pada tiga klasifikasi kerawanan banjir tinggi, sedang maupun rendah pada kawasan perkotaan Sinjai, yang dimana peneliti mencoba mengatur atau memberi usulan peraturan zonasi dan perizinan pada setiap pola ruang yang terdampak bencana banjir di setiap klasifikasi kerawanan yang berada pada Peta Rencana Detail Tata Ruang kawasan perkotaan Sinjai.

Rujukan yang di pakai dalam analisis amplop ruang kali ini iyalah Rencana Detail Tata Ruang dan Peraturan Zonsi Kawasan Perkotaan Sinjai Tahun 2013-2033, yang dimana dalam analisis ini untuk menjawab rumusan masalah ketiga yakni bagaimana konsep pengendalian pemanfaatan ruang kawasan terdampak banjir di perkotaan Sinjai. Adapun peraturan zonasi dan usulan perizinan dapat diuraikan sebagai berikut :

\section{a) Peraturan Zonasi dan Usulan Perizinan}

Ketentuan kegiatan dan penggunaan lahan untuk kawasan rawan banjir pada kawasan perkotaan Sinjai yang sesuai dengan jumlah klasifikasi kerawanan banjir yaitu tinggi, sedang maupun rendah. Masing-masing kawasan yang terdampak banjir tersebut pada dasarnya harus memiliki ketentuan kegiatan dan penggunaan lahan yang sesuai dengan kharakteristik pada masing-masing kawasan tersebut. Adapun ketentuan kegiatan dan penggunaan lahan pada kawasan rawan banjir tinggi, sedang maupun rendah dapat dijabarkan pada tabel sebagai beriku :

Tabel 8. Intensitas Pemanfaatan Ruang Kawasan Terdampak Banjir Di Perkotaan Sinjai

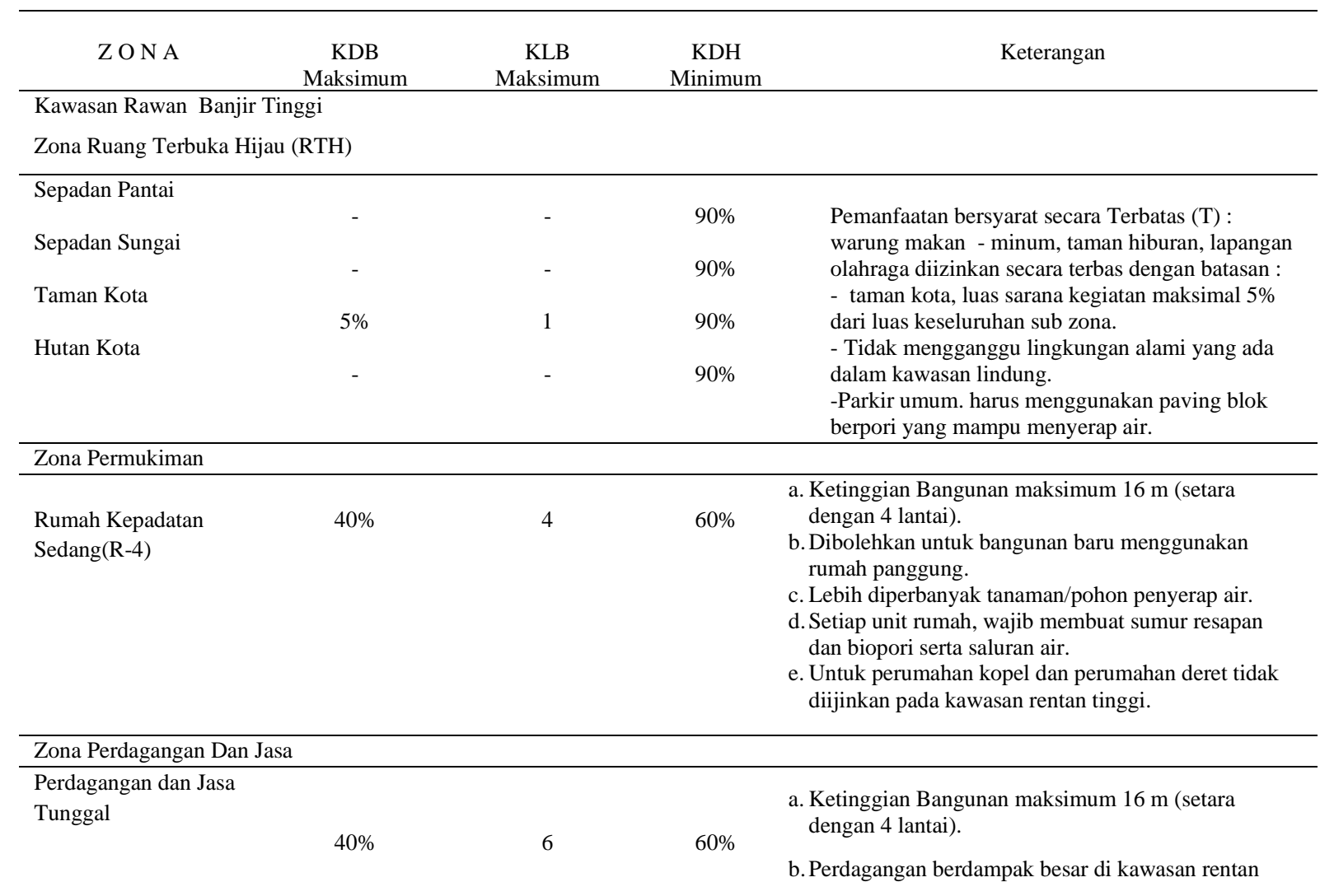


Muhammad Afandi Naser, Murshal Manaf, Tri Budiharto/ Journal of Urban and Regional Spatial. Vol 01 No 02. Hal 147-164

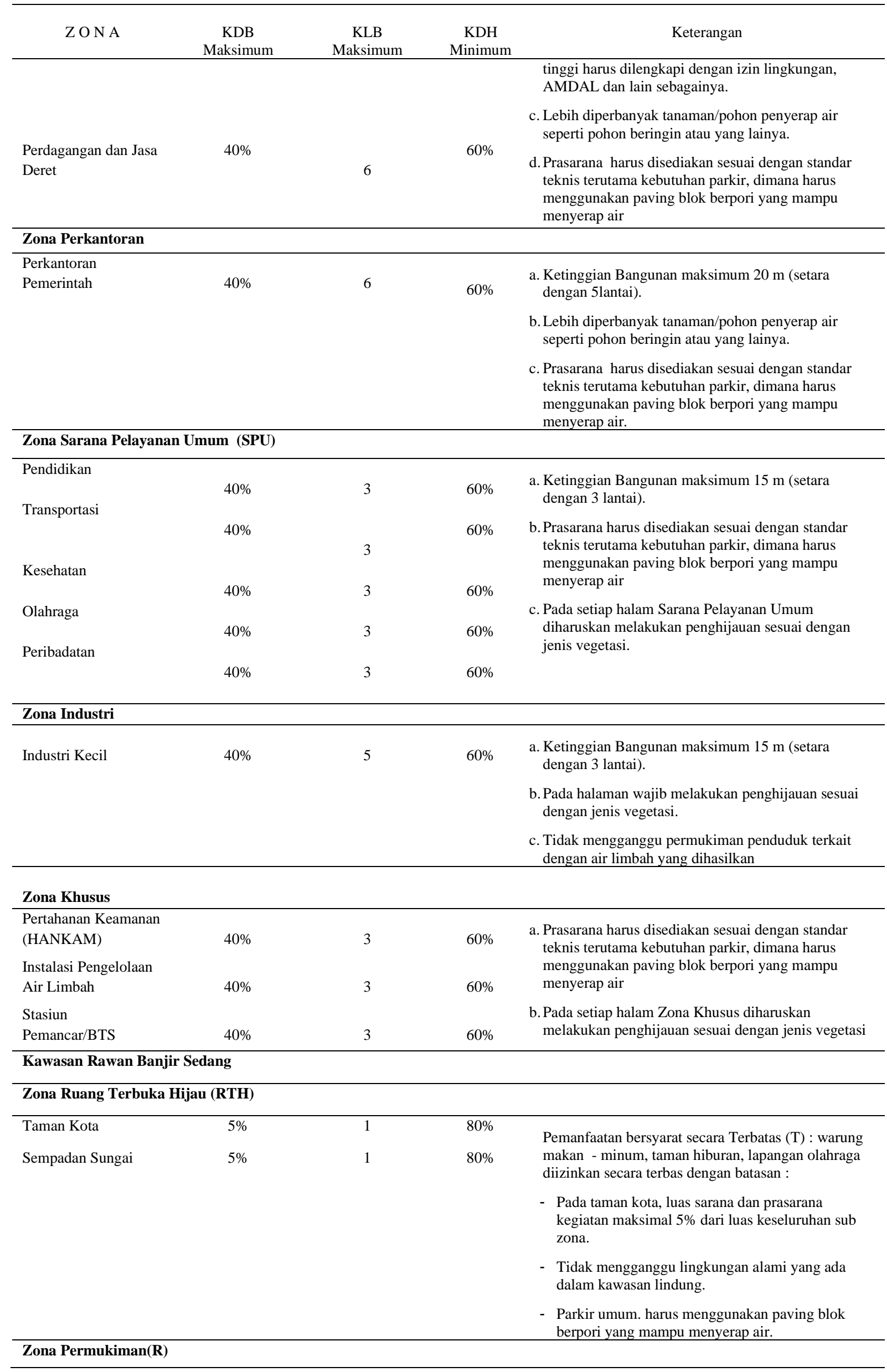


Muhammad Afandi Naser, Murshal Manaf, Tri Budiharto/ Journal of Urban and Regional Spatial. Vol 01 No 02. Hal 147-164

\begin{tabular}{|c|c|c|c|c|}
\hline $\mathrm{ZONA}$ & $\begin{array}{c}\text { KDB } \\
\text { Maksimum }\end{array}$ & $\begin{array}{c}\text { KLB } \\
\text { Maksimum } \\
\end{array}$ & $\begin{array}{c}\mathrm{KDH} \\
\text { Minimum }\end{array}$ & Keterangan \\
\hline $\begin{array}{l}\text { Rumah Kepadatan } \\
\text { Rendah(R-3) }\end{array}$ & $45 \%$ & 3 & $55 \%$ & $\begin{array}{l}\text { a. Ketinggian Bangunan maksimum } 16 \mathrm{~m} \text { (setara } \\
\text { dengan } 4 \text { lantai). } \\
\text { b. Dibolehkan untuk bangunan baru menggunakan } \\
\text { rumah panggung. }\end{array}$ \\
\hline $\begin{array}{l}\text { Rumah Kepadatan } \\
\text { Sedang(R-4) }\end{array}$ & $45 \%$ & 3 & $55 \%$ & $\begin{array}{l}\text { c. Lebih diperbanyak tanaman/pohon penyerap air } \\
\text { d. Setiap unit rumah, wajib membuat sumur resapan } \\
\text { dan biopori serta saluran air. }\end{array}$ \\
\hline \multicolumn{5}{|c|}{ Zona Perdagangan Dan Jasa (K) } \\
\hline $\begin{array}{l}\text { Perdagangan Dan Jasa } \\
\text { Tunggal(K-1) }\end{array}$ & $45 \%$ & 6 & $55 \%$ & $\begin{array}{l}\text { a. Ketinggian Bangunan maksimum } 16 \mathrm{~m} \text { (setara } \\
\text { dengan } 4 \text { lantai). }\end{array}$ \\
\hline $\begin{array}{l}\text { Perdagangan Dan Jasa } \\
\text { Deret(K-3) }\end{array}$ & $45 \%$ & 6 & $55 \%$ & $\begin{array}{l}\text { b. Perdagangan berdampak besar di kawasan rentan } \\
\text { tinggi harus dilengkapi dengan izin lingkungan, } \\
\text { AMDAL dan lain sebagainya. } \\
\text { c. Lebih diperbanyak tanaman/pohon penyerap air } \\
\text { seperti pohon beringin atau yang lainya. } \\
\text { d. Prasarana harus disediakan sesuai dengan standar } \\
\text { teknis terutama kebutuhan parkir, dimana harus } \\
\text { menggunakan paving blok berpori yang mampu } \\
\text { menyerap air }\end{array}$ \\
\hline \multicolumn{5}{|l|}{ Zona Perkantoran(KT) } \\
\hline $\begin{array}{l}\text { Perkantoran } \\
\text { Pemerintah(KT-1) }\end{array}$ & $45 \%$ & 6 & $55 \%$ & $\begin{array}{l}\text { a. Ketinggian Bangunan maksimum } 20 \text { m (setara } \\
\text { dengan 5lantai). } \\
\text { b. Lebih diperbanyak tanaman/pohon penyerap air } \\
\text { seperti pohon beringin atau yang lainya. } \\
\text { c. Prasarana harus disediakan sesuai dengan standar } \\
\text { teknis terutama kebutuhan parkir, dimana harus } \\
\text { menggunakan paving blok berpori yang mampu } \\
\text { menyerap air }\end{array}$ \\
\hline \multicolumn{5}{|c|}{ Zona Sarana Pelayanan Umum(SPU) } \\
\hline Pendidikan & $45 \%$ & 3 & $55 \%$ & $\begin{array}{l}\text { a. Ketinggian Bangunan maksimum } 15 \text { m (setara } \\
\text { dengan } 3 \text { lantai). }\end{array}$ \\
\hline Kesehatan & $45 \%$ & 4 & $55 \%$ & $\begin{array}{l}\text { b. Prasarana harus disediakan sesuai dengan standar } \\
\text { teknis terutama kebutuhan parkir, dimana harus } \\
\text { menggunakan paving blok berpori yang mampu }\end{array}$ \\
\hline Olahraga & $45 \%$ & 3 & $55 \%$ & menyerap air \\
\hline Peribadatan & $45 \%$ & 3 & $55 \%$ & $\begin{array}{l}\text { c. Pada setiap halam Sarana Pelayanan Umum wajib } \\
\text { melakukan penghijauan sesuai dengan jenis vegetasi. }\end{array}$ \\
\hline
\end{tabular}

\begin{tabular}{|c|c|c|c|c|}
\hline \multicolumn{5}{|c|}{ Zona Peruntukan Lainya (PL) } \\
\hline Parwisata & $45 \%$ & 2 & $55 \%$ & $\begin{array}{l}\text { a. Ketinggian bangunan maksimal } 8 \mathrm{~m} \text { (setara dengan } 2 \\
\text { lantai) } \\
\text { b. Prasarana harus disediakan sesuai dengan standar } \\
\text { teknis terutama kebutuhan parkir, dimana harus } \\
\text { menggunakan paving blok berpori yang mampu } \\
\text { menyerap air }\end{array}$ \\
\hline \multicolumn{5}{|c|}{ Kawasan Rawan Banjir Rendah } \\
\hline \multicolumn{5}{|c|}{ Zona Ruang Terbuka Hijau (RTH) } \\
\hline Taman Kota & $10 \%$ & 2 & $80 \%$ & $\begin{array}{l}\text { Pemanfaatan bersyarat secara Terbatas }(\mathrm{T}) \text { : } \\
\text { warung makan - minum, taman hiburan, lapangan } \\
\text { olahraga diizinkan secara terbas dengan batasan : } \\
\text { - Pada taman kota, luas sarana dan prasarana } \\
\text { kegiatan maksimal 10\% dari luas keseluruhan sub } \\
\text { zona. } \\
\text { - Tidak mengganggu lingkungan alami yang ada } \\
\text { dalam kawasan lindung. } \\
\text { - Parkir umum. harus menggunakan paving blok }\end{array}$ \\
\hline
\end{tabular}


Muhammad Afandi Naser, Murshal Manaf, Tri Budiharto/ Journal of Urban and Regional Spatial. Vol 01 No 02. Hal $147-164$

\begin{tabular}{cccc}
\hline Z O A & KDB & KLB & KDH \\
Maksimum & Maksimum & Minimum & Keterangan \\
\hline
\end{tabular}

berpori yang mampu menyerap air.

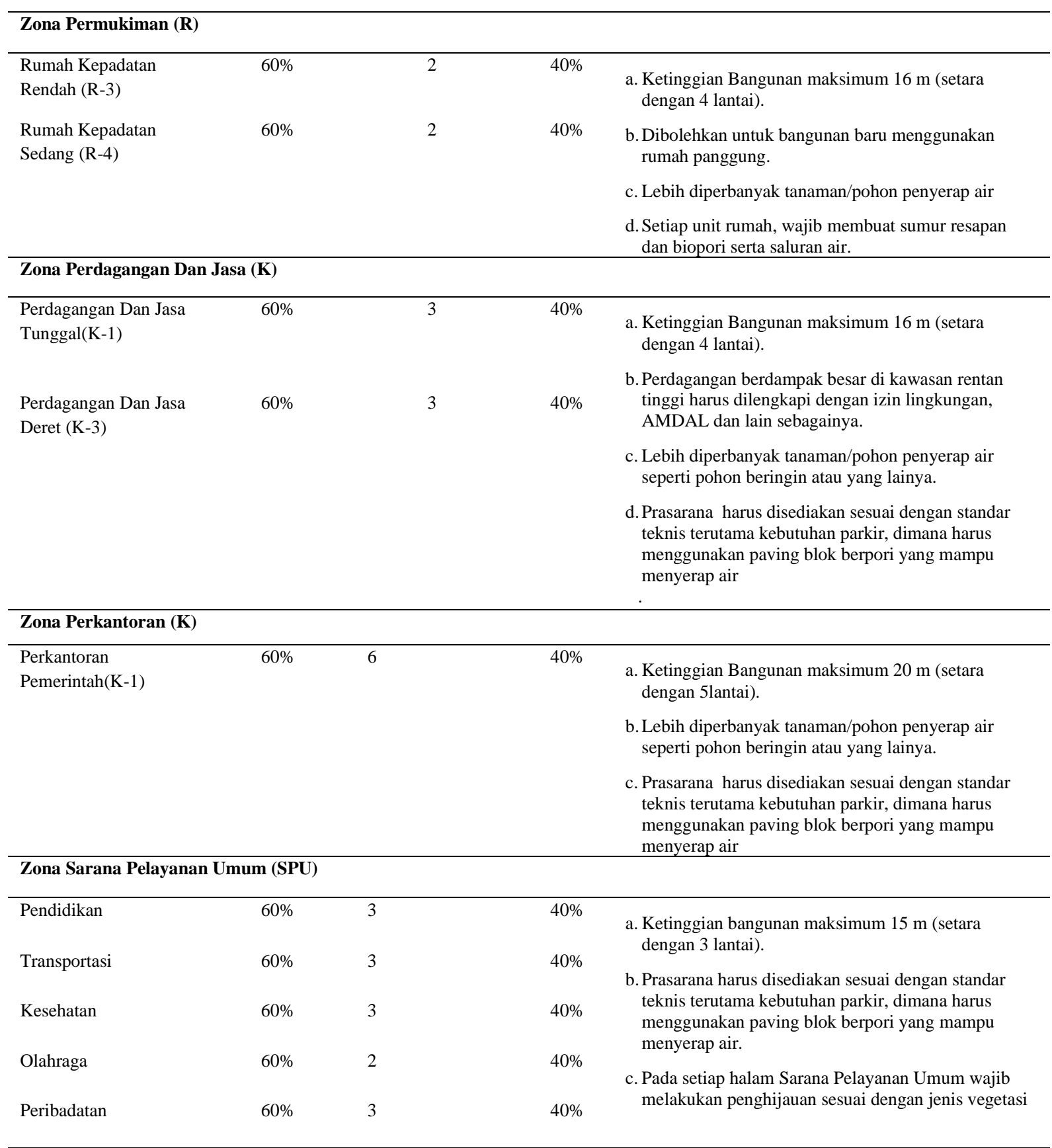

Kawasan rawan terdampak banjir di kawasan perkotaan Sinjai sangat penting untuk penerapkan konsep KDB, KLB dikarenakan konsep tersebut dapat mengatur kebutuhan lahan terbangun dan kebutuhan ruang terbuka hijau yang efesien dalam meminimalisir ancaman bencana banjir tiap tahun yang terjadi di kawasan perkotaan Sinjai. Terlebih lagi dengan konsep KDB ditetapkan dengan mempertimbangkan tingkat pengisian atau peresapan air, kapasitas drainase, dan jenis penggunaan lahan. Dari hasil analisis tersebut dapat diketahui bahwa, ada beberapa perbedaan perilaku pemberian perizinan pada kawasan rawan banjir tinggi, sedang maupun rendah. Usulan perizinan ini berbeda dengan yang terdapat pada dokumen Rencana Detail Tata Ruang kawasan perkotaan Sinjai dikarenakan pada usulan perizinan ini peneliti mengeluarkan arahan perizinan sesuai dengan kharakteristik kerawanan bencana banjir pada kawasan perkotaan Sinjai. Semoga usulan perizinan ini dapat bermanfaat bagi pemerintah maupun masyarakat yang berada di kawasan rawan banjir tinggi, sedang maupun rendah, yang tersapat pada kawasan perkotaan Sinjai. 


\section{KESIMPULAN}

Berdasarkan data dan hasil analisis yang dilakukan, maka dihasilkan kesimpulan berdasarkan tujuan dari penelitian yang dilakukan sebagai berikut: Tingkat rawan banjir di kawasan perkotaan Sinjai diklasifikasikan menjadi tiga yaitu kawasan rawan banjir rendah, kawasan rawan banjir sedang dan kawasan rawan banjir tinggi : dan kawasan rawan banjir yang lebih berdominan di kawasan perkotaan Sinjai adalah Kawasan rawan banjir sedang yang memiliki luas 1.713.259 Ha atau 42\% dari luas kawasan perkotaan Sinjai. Kemudian hasil kesesuaian penggunaan lahan terhadap RDTR kawasan perkotaan Sinjai terdapat kesesuaian pemanfaatan ruang (Sesuai) lebih mendominasi yang memiliki luas sebesar 2.891.388 Ha. Namun terdapat penyimpangan pemanfaatan ruang di kawasan perkotaan Sinjai yang pembangunannya tidak sesuai dengan rencana pemanfaatan ruang yang sudah di tetapkan, pada penggunaan lahan yang tidak sesuai dengan rencana pemanfaatan ruang memiliki luas sebesar 1.056.644 Ha. Kemudian pada Rencana Detail tata ruang kawasan rawan banjir, hasil analisis yang di dapatkan bahwasanya yang paling berdominan terdapat di kerawanan banjir tinggi yaitu perumahan yang dimana luasan kawasan perumahan yang rawan banjir adalah 564.185 Ha. yang tersebar di 5 kelurahan di kawasan perkotaan yaitu Kelurahan Balangnipa, Kelurahan Bringere, Kelurahan Bongki, Kelurahan Lappa dan Kelurahan Samataring. Dalam hasil anailsis deskriptif kualitatif dan analisis amplop ruang yang telah dilakukan, pengelolaan kawasan rawan banjir bedasarkan mitigasi struktural diantaranya adalah melakukan normalisasi bibir sungai, tanggul penahan banjir, sistem polder dan sistem perbaikan drainase sedangkan mitigasi non-struktural diantaranya adalah pengelolaan DAS dan pengaturan tata guna lahan, dan dalam hasil peraturan zonasi dan usulan perizinan yang hasilnya menetapkan bahwa kawasan rawan banjir tinggi, sedang maupun rendah di perkotaan Sinjai harus menerapkan konsep KDB, KLB serta $\mathrm{KDH}$. dikarenakan konsep tersebut dapat mengatur kebutuhan lahan terbangun dan kebutuhan ruang terbuka hijau yang efesien dalam meminimalisir ancaman bencana banjir tiap tahun yang terjadi di kawasan perkotaan Sinjai.

\section{DAFTAR PUSTAKA}

Cahyadi, A., Yananto, A., Wijaya, M. S., \& Nugraha, H. (2012). Analisis Pengaruh Perubahan Penggunaan Lahan Terhadap Retensi Potensial Air Oleh Tanah Pada Kejadian Hujan Sesaat (Studi Kasus Perubahan Penggunaan Lahan Di Das Garang Jawa Tengah). 7.

Emelyana, R., Sasmito, B., \& Prasetyo, Y. (2017). Jurnal Geodesi Undip. 6, 9.

Gina, B. U. S. (N.D.). Modul 4 Metode Pengendalian Banjir. 54.

Gunawan, D. W., Hartati, S. J., Maulana, Y. M., \& Baruk, J. R. K. (2014). Rancang Bangun Aplikasi Analisis Kredit Menggunakan Metode Skoring Pada Bintang Jaya Variasi Audio. 3(2), 7.

Hikmah, H. (2019). Pengaruh Disiplin Kerja Dan Kompetensi Terhadap Kinerja Pegawai (Studi Kasus Pada Pusat Penelitian Kebijakan Pendidikan Dan Kebudayaan Kementerian Pendidikan Dan Kebudayaan). Jebi | Jurnal Ekonomi Bisnis Indonesia, 13(2), 1-9. Https://Doi.Org/10.36310/Jebi.V13i2.98

Journal Of Business Studies. (2016). 2(1), 16.

Kautsary, J. (2018). Perencanaan Peraturan Zonasi Di Kawasan Konservasi (Studi Kasus Pecinan Semarang). Jurnal Planologi, 15(2), 216. Https://Doi.Org/10.30659/Jpsa.V15i2.3526

Mahendra, I. (N.D.). Analisa Penerimaan Pengguna Sistem Informasi Koperasi Pada Koperasi Karyawan Budi Setia Jakarta Dengan Technology Acceptance Model. 11.

Mukhsin, R., Mappigau, P., \& Tenriawaru, A. N. (N.D.). Pengaruh Orientasi Kewirausahaan Terhadap Daya Tahan Hidup Usaha Mikro Kecil Dan Menengah Kelompok Pengolahan Hasil Perikanan Di Kota Makassar. 6.

Muuzi, M., Surya, B., \& Aksa, K. (N.D.). Journal Of Urban Planning Studies. 01(01), 20.

Pradana, M., \& Reventiary, A. (2016). Pengaruh Atribut Produk Terhadap Keputusan Pembelian Sepatu Merek Customade (Studi Di Merek Dagang Customade Indonesia). 6, 10.

Priyono, B. (N.D.). Perizinan Sebagai Sarana Pengendalian Penataan Ruang Dalam Perspektif Pemanfaatan Ruang Di Daerah. 22.

Putri, P. D. (N.D.). Pengendalian Pemanfaatan Ruang Melalui Perizinan. 77.

Badan Pusat Statistik Kabupaten Sinjai. (2019). Kabupaten Sinjai Dalam Angka Tahun 2019. Makassar : Badan Pusat Statistik.

Badan Pusat Statistik Kabupaten Sinjai. (2019). Kecamatan Sinjai Utara Dalam Angka Tahun 2019. Makassar : Badan Pusat Statistik. 
Muhammad Afandi Naser, Murshal Manaf, Tri Budiharto/ Journal of Urban and Regional Spatial. Vol 01 No 02. Hal 147-164

Badan Pusat Statistik Kabupaten Sinjai. (2019). Kecamatan Sinjai Timur Dalam Angka Tahun 2019. Makassar : Badan Pusat Statistik.

Peraturan Daerah nomor 28 Tahun 2012 tetang Rencana Tata Ruang Wilayah Kabupaten Sinjai Tahun 2012 2032.

Peraturan Daerah nomor 02 Tahun 2018 tentang Rencana Detail Tata Ruang Dan Peraturan Zonasi Kawasan Perkotaan Sinjai Tahun 2018 - 2038. 